\title{
PARTNERSTWO PUBLICZNO-PRYWATNE W PERSPEKTYWIE ROKU 2020. PPP JAKO MECHANIZM FINANSOWANIA REWITALIZACJI MIAST
}

\section{Wstęp}

Po długim okresie dominacji gospodarki centralnie planowanej w Polsce życiem gospodarczym zaczęły kierować prawa rynku. Prawa i regulacje rynkowe dotyczą wszystkich podmiotów działających na rynku, przedsiębiorstw, instytucji finansowych, konsumentów, a także instytucji publicznych, które biorą udział w życiu gospodarczym. Do takich instytucji należą samorządy lokalne, które przejęły odpowiedzialność za zarządzany teren. Odpowiedzialność ta zmusiła władze samorządowe do myślenia o swoim terenie jak o własnym gospodarstwie. Jednym z nowych celów, jakie postawiły przed sobą samorządy, jest odnowa wizerunku gmin i miast, polepszenie ich postrzegania w społeczeństwie oraz zwiększenie ich wartości w regionie. Osiągnięcie tych celów jest możliwe, między innymi dzięki rewitalizacji. Działania rewitalizacyjne są podejmowane coraz częściej przez samorządy. W kilkunastoletniej historii wysiłków rewitalizacyjnych w Polsce nie obyło się jednak bez problemów z jej przeprowadzeniem. Jednym z takich problemów była na pewno kwestia finansowania założonego procesu.

Wielu samorządom brakuje środków finansowych na realizację programów rewitalizacji, jakie byłyby wymagane dla danego obszaru. W związku z tym zaangażowanie prywatnych kapitałów w działania związane z odnową przestrzeni publicznej pozwoliłoby zrealizować przedsięwzięcia, na sfinansowanie których brak jest środków budżetowych.

Celem pracy jest analiza zakresu stosowania formuły partnerstwa publiczno-prywatnego (PPP) w Polsce w 2011 roku oraz ocena możliwości jej zastosowania przy realizacji programów rewitalizacji miast.

Praca składa się $\mathrm{z}$ części teoretycznej, przedstawionej $\mathrm{w}$ trzech pierwszych częściach, oraz części empirycznej, zaprezentowanej w części czwartej. Część empiryczna pracy opiera się na analizie stanu faktycznego stosowania PPP w Polsce w 2011 roku. Wnioski dotyczące rozwoju PPP $\mathrm{w}$ procesach rewitalizacji miast $\mathrm{w}$ Polsce $\mathrm{w}$ najbliższych latach prezentuje podsumowanie.

\section{Rewitalizacja a PPP}

Rewitalizacja to proces, który składa się nie tylko z działań mających na celu odnowę zdegradowanej substancji miejskiej. Rewitalizacja to także

\footnotetext{
* Doktorant, Wydział Zarządzania, Uniwersytet Łódzki.
} 
odnowa w sferze społecznej danego obszaru. Instytutu Rozwoju Miast jako rewitalizację określa „skoordynowany proces, prowadzony wspólnie przez władzę samorządową, społeczność lokalną i innych uczestników, będący elementem polityki rozwoju i mający na celu przeciwdziałania degradacji przestrzeni zurbanizowanej, zjawiskom kryzysowym, pobudzanie rozwoju i zmian jakościowych, poprzez wzrost aktywności społecznej i gospodarczej, poprawę środowiska zamieszkania oraz ochronę dziedzictwa narodowego, przy zachowaniu zasad zrównoważonego rozwoju"”.

Aby programy rewitalizacji osiągnęły założone cele, instytucje odpowiedzialne za ich realizację muszą działać kompleksowo - tak w sferze urbanistycznej, jak i gospodarczej, czy społecznej. Kompleksowość ta wymusza, pośród wielu innych działań, zaangażowanie znacznych nakładów finansowych. Często przerasta to możliwości gmin. Gminy powinny więc szukać nowych źródeł, czy mechanizmów finansowania. Jednym $\mathrm{z}$ mechanizmów może być niedoceniane $\mathrm{w}$ Polsce partnerstwo publicznoprywatne.

Inwestycje związane z rewitalizacją miast charakteryzują się wysokim stopniem ryzyka i często nie przynoszą zysków, jednak są bardzo potrzebne ze względów społecznych. Tadeusz Markowski ${ }^{2}$ podkreśla konieczność współfinansowania rewitalizacji przez partnerów prywatnych. Stwierdza, że aby zmniejszyć ryzyko inwestycji związanych $\mathrm{z}$ rewitalizacją, trzeba doprowadzić do dużego skumulowania inwestorów. Niezbędna jest tu współpraca między władzą publiczną, która posiada nieruchomości i prawną legitymizację rozporządzania mieniem, a partnerami prywatnymi, którzy posiadają kapitał.

To co istotne w partnerstwie publiczno-prywatnym to wspólnota działań sektora publicznego i prywatnego tworzona po to, aby obaj partnerzy wspólnego działania mogli dobrze realizować swoje cele, dla których zostali powołani. Partner publiczny ma świadczyć usługi publiczne, do czego zobowiązują go przepisy prawa. Partner prywatny ma za zadanie osiąganie zysków z prowadzenia działalności gospodarczej.

W procesie właściwie wykonanej rewitalizacji podmioty biorące $\mathrm{w}$ niej udział otrzymują swoistą rentę rewitalizacyjną, z której płyną odpowiednie korzyści dla partnera publicznego i prywatnego. Korzyścią partnera prywatnego jest niewątpliwie zysk. Partner publiczny osiąga korzyści, które przekładają się na rewitalizowany obszar oraz na całe miasto. Odnowiony obszar, siłą inercji, powinien dać impuls rozwojowy dla całego miasta oraz doprowadzić do efektu dyfuzji - rozpowszechniania się na inne obiekty i tereny czekające na

\footnotetext{
1 www.fr.org.pl/index.php?option=com_content\&task=view\&id=219\&Itemid=114, dostęp na 12.05.2012.

${ }^{2}$ T. Markowski, D. Stawasz, Rewitalizacja a rozwój funkcji metropolitalnych miasta Łodzi, Wydawnictwo UŁ, Łódź 2007, s. 38.
} 
przywrócenia do życia ${ }^{3}$. Zwiększa się wówczas wartość rewitalizowanego obszaru oraz całego miasta. Pod warunkiem zwiększenia zabudowy, zwiększają się wpływy miasta $\mathrm{z}$ podatków od nieruchomości. Poza tym władze samorządowe odnoszą korzyści polityczne.

Wspólnym interesem obu podmiotów jest więc efekt dyfuzji, który dla miasta powoduje rozprzestrzenianie się efektów rewitalizacji i odnawianie nowych obszarów, a dla partnera prywatnego powstanie zwiększonego zysku.

PPP stosowane jest w działaniach, w których realizacja działań wyłącznie przez sektor publiczny nie jest - ze względów finansowych i organizacyjnych korzystna. Najczęściej więc do modelu PPP sięga się przy realizacji projektów infrastrukturalnych, w takich dziedzinach jak: transport, ochrona zdrowia, edukacja, bezpieczeństwo, rewitalizacja. Do projektów realizowanych w formule partnerstwa należeć mogą baseny i parki wodne, parkingi, gospodarka odpadami, czy transport publiczny.

Model PPP może być stosowany przy rewitalizacji zdegradowanych terenów przemysłowych, prowadzonej przez podmioty sektora prywatnego, za której wykonanie podmioty sektora prywatnego otrzymywać będą np. prawo użytkowania nieruchomości. W ten sposób zysk partnerów prywatnych mógłby przybrać postać czynszu pobieranego z wynajmowanych lub wydzierżawianych nieruchomości. W podobny sposób tereny zanieczyszczone mogłyby być poddawane rekultywacji. Partnerstwo można wykorzystać do odnowy budynków, bądź też ogólnie do zaspokojenia potrzeb mieszkaniowych. Gmina w tym przypadku przekazuje grunty, a prywatna firma buduje określoną w umowie liczbę mieszkan. Przez okres umowny mieszkaniami zarządza partner prywatny, czerpiąc zyski z pobieranych czynszów (ich wysokość określa gmina).

\section{Istota i zakres partnerstwa publiczno-prywatnego}

Partnerstwo publiczno-prywatne to instrument używany do realizacji zadań publicznych. Uznaje się je nie tylko za interesującą koncepcję teoretyczną, ale także za narzędzie, które może się sprawdzić w sprawnym zarządzaniu realizacją zadań publicznych. Cechuje je elastyczność podejścia, umożliwiająca stosowanie nowych metod zarządzania w sektorze publicznym ${ }^{4}$.

Istnieje wiele definicji PPP. Jedna $\mathrm{z}$ nich określa termin partnerstwa publiczno-prywatnego jako procesy inwestycyjne i eksploatacyjne, realizowane w oparciu o umowy długoterminowe przez władze publiczne i podmioty

\footnotetext{
${ }^{3}$ J. Rutkowski (red.), Partnerstwo publiczno-prywatne w Polsce i jego funkcjonowania na przyktadzie wybranych projektów, Wydawnictwo Uniwersytetu Łódzkiego, Łódź 2010. s. 291.

${ }^{4}$ A. Kopańska, A. Bartczak, J. Siwińska-Gorzelak, Partnerstwo publiczno-prywatne. Podmioty prywatne $w$ realizacji zadań publicznych sektora wodno-kanalizacyjnego, Wydawnictwo DIFIN, Warszawa 2008, s. 20.
} 
prywatne, których celem jest tworzenie infrastruktury rzeczowej, finansowej i organizacyjnej, która umożliwia świadczenie usług publicznych ${ }^{5}$.

PPP charakteryzuje się tym, że strona publiczna sprawuje władztwo administracyjne, co daje jej wpływ na możliwości i warunki prowadzenia działalności gospodarczej poprzez decydowanie o udzielaniu koncesji, czy pozwoleń. Podmiot publiczny dysponuje też mieniem o strategicznym znaczeniu dla rozwoju danego obszaru, czyli szeroko pojętą infrastrukturą. Partner prywatny z kolei posiada wiedzę, dysponuje technologią i kapitałem, a także cechuje go wyższa efektywność działania. W aspekcie prawnym istotą PPP jest powierzenie partnerowi prywatnemu zadań publicznych, przy zachowaniu przez podmiot publiczny odpowiedzialności publicznoprawnej za wykonanie tych zadań ${ }^{6}$.

Wynika z tego, że istotą partnerstwa publiczno-prywatnego jest współpraca strony publicznej i prywatnej w trakcie realizacji wspólnych zadań. Do współpracy dochodzi zazwyczaj, gdy podmiot publiczny nie jest w stanie unieść ciężaru dużego projektu inwestycyjnego ${ }^{7}$. Realizacja zadań w formie PPP daje możliwość osiągnięcia wspólnych korzyści, ale także niesie za sobą wiele ryzyk. Literatura przedmiotu opisuje dokładnie zarówno dobre strony $\mathrm{PPP}^{8}$, jak i problemy związane z jego stosowaniem ${ }^{9}$.

Problemy moga być zniwelowane poprzez podniesienie wiedzy o PPP i jego mechanizmach działania oraz ogólnych umiejętności związanych z planowaniem i realizacją inwestycji przez samorządy. Ryzyko współpracy z partnerem prywatnym zmniejszyłoby się także w przypadku podniesienia poziomu ochrony prawnej podmiotu publicznego.

\section{Formy organizacyjne współpracy w ramach PPP}

Współpraca podmiotu publicznego z partnerem prywatnym $\mathrm{w}$ trakcie realizacji zadań publicznych może przybierać różne formy organizacyjne. Wśród nich znajdują się kontraktowanie, współpraca w formule BOT, BOOT, ROT, DBFO. Współpraca może także przyjąć formę spółki lub być realizowana $\mathrm{w}$ formie koncesji.

Partnerstwo w formule BOT (build, operate, transfer, czyli wybuduj, eksploatuj/zarządzaj, przekaż) obejmuje zaprojektowanie obiektu, jego budowę oraz eksploatację przez $\mathrm{z}$ góry określony czas. W ramach takiej formuły partnerstwa obiekt jest finansowany przez sektor publiczny i pozostaje jego

\footnotetext{
${ }^{5}$ I. Herbst, Warunki finansowania procesów rewitalizacji w gospodarce rynkowej, [w:] Bryx M. (red.), Finansowanie $i$ gospodarka nieruchomościami $w$ procesach rewitalizacji, Instytut Rozwoju Miast, Kraków 2009, s. 134.

${ }^{6}$ J. Rutkowski, (red.), Partnerstwo publiczno-prywatne w Polsce..., op. cit., s.33.

${ }^{7}$ Tamże, s. 308.

${ }^{8}$ Cz. Rudzka-Lorentz, J. Sierak, Zarządzanie finansami w gminach, [w:] SochackaKrysiak H. (red.), Zarzadzanie gospodarka i finansami gminy, Oficyna Wydawnicza Szkoły Głównej Handlowej, Warszawa 2006, s. 221.

${ }^{9}$ J. Rutkowski, (red.), Partnerstwo..., s. 99-106.
} 
własnością. Powodem wyboru takiego partnerstwa jest przeniesienie nie tylko ryzyka projektowego i budowlanego, ale także tego związanego z eksploatacją i zarządzaniem obiektem. Partnerstwo w tej formie sprawdza się w sektorach, takich jak gospodarka wodna, czy odpadami lub gdy zarządzanie obiektem jest procesem trudnym i złożonym, wymagającym specjalistycznej wiedzy.

Odmianami partnerstwa typu BOT są formy BOOT i ROT. BOOT (build, own, operate, transfer, czyli buduj, bądź właścicielem, eksploatuj/zarządzaj, przekaż) różni się od klasycznego BOT czasowym przeniesieniem praw własności na podmiot prywatny. ROT (rehabilitate, operate, transfer, czyli przywróć do stanu używalności, eksploatuj, przekaż) polega na tym, że dany obiekt już istnieje, a zadaniem partnera prywatnego jest jego rehabilitacja lub podniesienie standardu użytkowego i funkcjonalnego.

Partnerstwo w formule DBFO przewiduje, że podmiot prywatny będzie odpowiedzialny za projekt, budowę oraz zarządzanie obiektem przez określony okres (design, build, finance, operate). Ponadto, w odróżnieniu od BOT, obiekt na czas trwania kontraktu staje się własnością strony prywatnej, która jest odpowiedzialna za pozyskanie finansowania projektu. Podczas zarządzania obiektem podmiot prywatny odzyskuje zainwestowane środki z subwencji przekazywanych przez podmiot publiczny.

Według polskiego ustawodawstwa ${ }^{10}$ umowa o partnerstwie publicznoprywatnym może przewidywać, że podmiot publiczny i partner prywatny dla realizacji określonego przedsięwzięcia powołają spółkę kapitałową, spółkę komandytową lub komandytowo-akcyjną. Jest to PPP w formie spółki. Podmiot publiczny nie może jednak w tym przypadku być komplementariuszem. Cel i zakres działalności takiej spółki nie może wykraczać poza zakres określony w umowie o PPP.

Inną formą współpracy $w$ ramach PPP są koncesje. Przypominają w zasadzie DBFO, z tą różnicą, że podmiot prywatny nie korzysta z subwencji publicznych, lecz odzyskuje poniesione koszty $\mathrm{z}$ opłat wnoszonych przez użytkownika obiektu. Koncesjonariusz ponosi tu w zasadniczej części ryzyko ekonomiczne wykonywania koncesji ${ }^{11}$. Forma ta opiera się na przepisach ustawy z 9 stycznia 2009 r. o koncesji na roboty budowlane lub usługi, która określa zasady i tryb zawierania umowy koncesji na roboty budowlane lub usługi oraz środki ochrony prawnej ${ }^{12}$.

\footnotetext{
${ }^{10}$ Ustawa z dnia19 grudnia 2008 r. o partnerstwie publiczno - prywatnym, tj. Dz. U. z 2009 r. Nr 19, poz. 100, z późn. zm.

${ }^{11}$ Przy opisie form organizacyjnych PPP wykorzystano materiały prezentowane przez dr. W. Walczaka na konferencji „Partnerstwo publiczno-prywatne w Polsce. Teoria a praktyka", która odbyła się w dn. 25-26 czerwca 2010r. w Ciążeniu. Konferencja zorganizowana została przez Katedrę Zarządzania Miastem i Regionem UŁ.

${ }^{12}$ Ustawa z dnia 9 stycznia 2009 o koncesji na roboty budowlane lub usługi, tj. Dz. U. z 2009r., nr 19, poz. 101, z późn. zm.
} 


\section{Rynek PPP w Polsce}

Rynek inwestycji planowanych do realizacji z partnerem prywatnym w Polsce szybko się zmienia, co przejawia się zarówno w liczbie sektorów, w których realizowane są tego typu inwestycje, jak i poprzez różnorodność podmiotów publicznych, które podejmują się projektów koncesyjnych i PPP.

Od początku 2009 roku liczba projektów publiczno-prywatnych w sposób naturalny zwiększała się i pod koniec 2011 roku sięgnęła już 144 przedsięwzięć. W 2011 roku podmioty publiczne zamieściły 42 ogłoszenia o projektach planowanych do współpracy z partnerami prywatnymi (24 ogłoszenia dotyczyły przedsięwzięć koncesyjnych, a 18 dotyczyło projektów ogłoszonych na podstawie ustawy o PPP). W roku 2011 ogłoszono aż 36 zupełnie nowych przedsięwzięć, nie będących powtórzeniem ogłoszeń z poprzednich lat. 28 ogłoszeń dotyczyło projektów zgłoszonych przez gminy i miasta.

W 2011 roku, podobnie jak w poprzednich latach, największą popularnością $\mathrm{w}$ zakresie projektów planowanych do realizacji z partnerami prywatnymi cieszył się sektor sportowo-rekreacyjny. Poza tym rynek skłaniał się w stronę projektów związanych $\mathrm{z}$ infrastrukturą miejską i komunalną. Ważnym sektorem w 2011 roku była infrastruktura miejska, w której ogłoszono aż 8 postępowań oraz gospodarka odpadami, w której ogłoszono 5 postępowań. Ogłoszono również cztery projekty parkingowe oraz po trzy w zakresie budownictwa komunalnego i edukacji (rysunek 1).

\section{Rysunek 1. Liczba ogloszeń w 2011 w podziale na sektory gospodarcze}

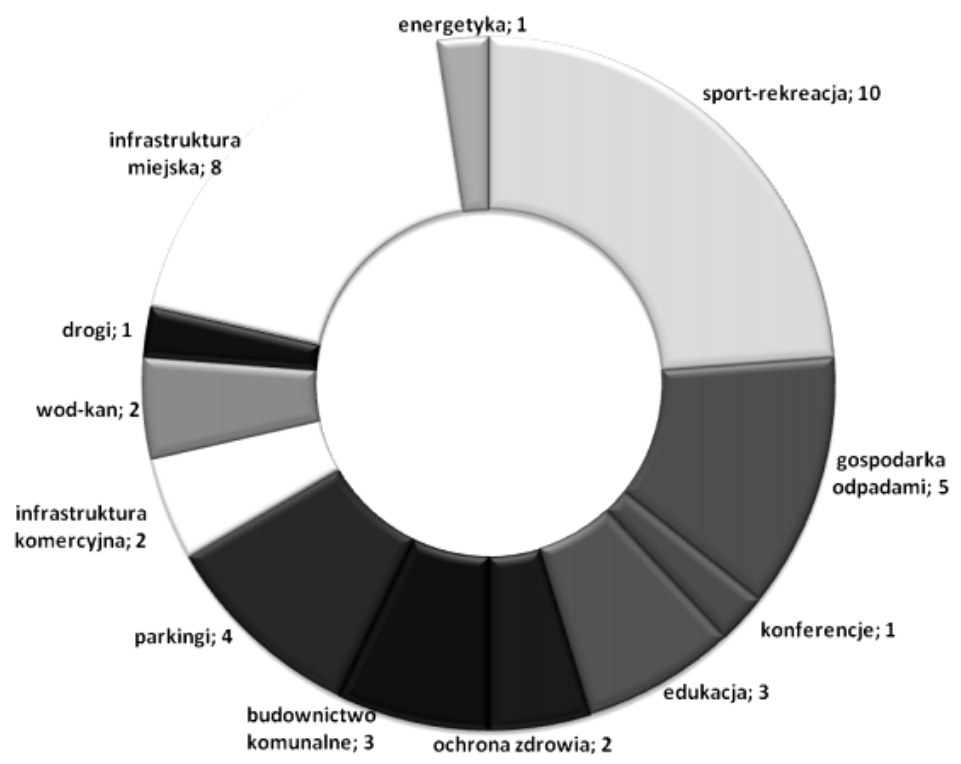

Źródło: Rynek PPP w Polsce 2011. Raport Investment Support na temat rynku partnerstwa publiczno-prywatnego i koncesji w 2011 r. Warszawa 2012, s. 12. 
W 2011 roku podpisano 11 umów z partnerami prywatnymi. W tym przypadku prym wiodły projekty w formule koncesji na usługi (aż 8 umów tego rodzaju). Sukcesem w postaci podpisanej umowy zakończyła się również jedna koncesja na roboty budowlane oraz dwa PPP w trybie koncesji.

W ciągu ostatnich trzech lat podpisano w sumie 27 umów z partnerami prywatnymi, z czego 11 to umowy o koncesji na usługi, 8 to umowy o koncesji na roboty budowlane, 5 umowy o PPP w trybie koncesji oraz 3 umowy o PPP w trybie PZP (Prawo zamówień publicznych $\left.{ }^{13}\right)^{14}$.

W obecnej chwili w Polsce są realizowane 33 projekty w różnych fazach ich realizacji, natomiast 69 projektów jest w fazie pomysłu. Województwa, w których zrealizowano najwięcej projektów $\mathrm{z}$ wykorzystaniem PPP, to województwa małopolskie (8 projektów), śląskie i wielkopolskie (odpowiednio 6 i 5 projektów). Najgorzej bilans ten przedstawia się w Lubelskiem, gdzie nie zrealizowano żadnego projektu oraz nie ma takich pomysłów ${ }^{15}$. W województwie łódzkim obecnie są realizowane trzy projekty $\mathrm{w}$ fazie pomysłu. Są to:

- Gospodarka odpadami komunalnymi w Łodzi - faza II.

- Program rewitalizacji domów familijnych.

- Zaprojektowanie, Budowa, Współfinansowanie i Eksploatacja Stadionu przy al. Piłsudskiego $138 \mathrm{w}$ Lodzi.

Najciekawszy jest program rewitalizacji domów familijnych na Księżym Młynie w Łodzi. W procesie rewitalizacji wykorzystany zostanie mechanizm zamiany nieruchomości. Zakłada on, że inwestor wybrany w drodze konkursu wybuduje nowe budynki mieszkalne, w których znajdować się będą lokale dla obecnych mieszkańców domów familijnych. Następnie przekaże nieruchomości zabudowane tymi budynkami na własność miastu, a w zamian otrzyma domy familijne. Inwestor musi utrzymać odpowiedni standard budynków i mieszkań, a także będzie zobowiązany zmodernizować domy familijne zgodnie z wytycznymi urbanistyczno - architektonicznymi oraz wytycznymi konserwatorskimi.

Programem objęte zostały trzy zespoły domów familijnych w Lodzi: na Księżym Młynie, pl. Zwycięstwa oraz przy ul. Ogrodowej. Są to unikalne kompleksy mieszkaniowe, które wraz z rezydencjami fabrykantów i zespołami budowli prezentujących ewolucję architektury industrialnej, stanowią dziedzictwo przemysłowej Łodzi. Szansą dla przywrócenia tym obiektom dawnej atrakcyjności jest właśnie ich rewitalizacja ${ }^{16}$.

\footnotetext{
${ }^{13}$ Ustawa z dnia 29 stycznia 2004 r. Prawo zamówień publicznych, tj. Dz. U. z 2007 r. nr 223, poz. 1655 , z późn. zm.

${ }^{14}$ Rynek PPP $w$ Polsce 2011. Raport Investment Support na temat rynku partnerstwa publiczno-prywatnego i koncesji w 2011 r., Warszawa 2012, s. 4-6.

${ }_{15}$ Ministerstwo Gospodarki, Baza projektów PPP, http://bazappp.gov.pl/project_base/, dostęp na 28.10.2012.

16 www.rewitalizacja.zabytki.lodz.pl/page/index.php?str=132\&id=28, dostęp na 28.10.2012.
} 
Przykładem zakończonego już projektu jest parking podziemny dwukondygnacyjny na 600 miejsc wraz z odbudową Międzyszkolnego Ośrodka Sportowego oraz z wjazdem i wyjazdem przy ul. Powiśle w Krakowie. Parking zbudowany został $\mathrm{w}$ systemie koncesji, gdzie wynagrodzeniem dla koncesjonariusza było oddanie parkingu w użytkowanie na 70 lat. Koncesję otrzymała hiszpańska firma ASCAN EMPRESA Y DE GESTION. Poza parkingiem i ośrodkiem sportowym firma ta wykonała remont nawierzchni ulic, chodników i zieleńców otaczających Plac Na Groblach ${ }^{17}$. Oddanie obiektu do użytku nastąpiło 9 grudnia 2009 roku.

\section{Podsumowanie}

Aby właściwie zrealizować założone cele programów rewitalizacji, samorządy zmuszone są sięgać po zewnętrzne źródła finansowania. Pomóc może w tym, między innymi, formuła partnerstwa publiczno-prywatnego. Formuła ta niesie jednak za sobą wiele wątpliwości i problemów w jej sprawnym stosowaniu.

Wykonanie projektów rewitalizacji obiektów o dużym znaczeniu kulturowym czy historycznym we współpracy z podmiotem prywatnym wymagać będzie formuły ROT, czyli przywrócenia do stanu używalności, eksploatacji, przekazania. Tereny powojskowe, poprzemysłowe, czy pokolejowe, które zmieniły swoje przeznaczenie, mogą być rewitalizowane z zastosowaniem innych reguł współpracy publiczno-prywatnej. W takich przypadkach najlepiej sprawdza się partnerstwo na zasadzie koncesji.

Partycypacja partnera prywatnego powinna być długotrwała, a odpowiednie metody promocji oraz czerpania korzyści nie powinny być postrzegane jako prywatyzacja dziedzictwa kulturowego. Udział partnera prywatnego powinien być widziany jako nowa jakość zarządzania, opartego na zdrowych zasadach zarządzania finansami oraz godzeniu interesu publicznego z prywatnym.

Dla wielu lokalnych polityków PPP to obszar trudny z uwagi na obawy przed złym społecznym odbiorem powiązań sektora publicznego i prywatnego. Z kolei problemy organizacyjne dotyczą skomplikowanych procedur przetargowych, które przeciągają postępowania przez wiele miesięcy. Procedura ta, zamiast przynosić korzyści, komplikuje realizację rewitalizacji. Inna obawa pojawiająca się ze strony samorządów to obawa przed ryzykiem. Instytucje publiczne starają się przerzucić całe ryzyko na partnera prywatnego, co skutkuje wzrostem kosztów całego przedsięwzięcia. Do obaw zaliczyć można także strach przed nieuczciwością strony prywatnej. Samorządy nie dysponują wystarczającym doświadczeniem oraz możliwościami, by skutecznie i szybko egzekwować właściwe wykonanie umowy.

Partnerstwo publiczno-prywatne jest niezbędne w zakresie wykorzystania dziedzictwa kulturowego $\mathrm{w}$ procesie rewitalizacji. Podmiotowi publicznemu

${ }^{17}$ www.bip.krakow.pl/?dok_id=23247, dostęp na 28.10.2012. 
trudno jest odnaleźć nowe funkcje i przeznaczenie rewitalizowanego obiektu, jeśli nie dysponuje kompletną informacją, płynącą z rynku.

Podstawową przyczyną niestosowania PPP w projektach rewitalizacyjnych w Polsce nie jest jednak źle sformułowana ustawa dotycząca zasad uruchamiania umowy o PPP, ani też niewątpliwy brak wiedzy władzy publicznej na temat partnerstwa. Podstawową przyczyną jest brak regulacji prawno-instytucjonalnych w zakresie samej rewitalizacji, nakładającej na obie strony prawa i obowiązki, a przede wszystkim brak nadania rewitalizacji atrybutów usługi publicznej, tak aby możliwe było zawieranie długookresowych umów cywilnoprawnych.

$\mathrm{W}$ polskich realiach istnieje potrzeba upowszechnienia wiedzy na temat możliwości realizowania zadań publicznych poprzez PPP. Konieczne jest właściwe i precyzyjne zdefiniowanie istoty partnerstwa, co pozwoli zaakceptować jego idee przez partnerów publicznych i prywatnych. Konieczne jest wprowadzenie odpowiednich uregulowań prawnych, aby nadać rewitalizacji status zadania publicznego oraz aby zarówno partnerzy publiczni, jak i prywatni znali zakres i możliwości współpracy przy realizacji programów rewitalizacji. Pozwoli to $\mathrm{w}$ ciągu najbliższych lat rozpowszechnić formułę PPP i z powodzeniem stosować ją w procesie odnowy przestrzeni publicznej.

\section{Bibliografia}

1. Ustawa z dnia 29 stycznia 2004 r. Prawo zamówień publicznych, tj. Dz. U. z 2007 r. nr 223, poz. 1655, z późn. zm.

2. Ustawa $z$ dnia19 grudnia 2008 r. o partnerstwie publiczno-prywatnym, tj. Dz. U. z 2009 r. Nr 19, poz. 100, z późn. zm.

3. Ustawa z dnia 9 stycznia 2009 o koncesji na roboty budowlane lub usługi, tj. Dz. U. z 2009 r. , nr 19, poz. 101, z późn. zm.

4. Herbst I., Warunki finansowania procesów rewitalizacji w gospodarce rynkowej, [w:] Bryx M. (red.), Finansowanie $i$ gospodarka nieruchomościami $w$ procesach rewitalizacji, Instytut Rozwoju Miast, Kraków 2009.

5. Kopańska A., Bartczak A., Siwińska-Gorzelak J., Partnerstwo publicznoprywatne. Podmioty prywatne $w$ realizacji zadań publicznych sektora wodno-kanalizacyjnego, Wydawnictwo DIFIN, Warszawa 2008.

6. Markowski T., Stawasz D., Rewitalizacja a rozwój funkcji metropolitalnych miasta Łodzi, Wydawnictwo UŁ, Łódź 2007.

7. Ministerstwo Gospodarki, Baza projektów PPP, http://bazappp.gov.pl /project_base/.

8. Rudzka-Lorentz Cz., Sierak J., Zarządzanie finansami w gminach, [w:] Sochacka-Krysiak H., (red.), Zarzadzanie gospodarka i finansami gminy, Oficyna Wydawnicza Szkoły Głównej Handlowej, Warszawa 2006.

9. Rutkowski J. (red.), Partnerstwo publiczno-prywatne $w$ Polsce i jego funkcjonowania na przykładzie wybranych projektów, Wydawnictwo Uniwersytetu Łódzkiego, Łódź 2010. 
10. Rynek PPP w Polsce 2011. Raport Investment Support na temat rynku partnerstwa publiczno-prywatnego i koncesji w 2011 r. Warszawa 2012.

11. Walczak W., „Partnerstwo publiczno-prywatne w Polsce. Teoria a praktyka", materiały konferencyjne, konferencja zorganizowana przez Katedrę Zarządzania Miastem i Regionem UŁ w dn. 25-26 czerwca 2010r. w Ciążeniu.

\section{Strony internetowe}

1. www.fr.org.pl.

2. www.rewitalizacja.zabytki.lodz.pl/page/index.php?str=132\&id=28.

3. www.bip.krakow.pl/?dok_id=232417.

\section{Streszczenie}

Tradycyjne źródła finansowania inwestycji komunalnych $w$ Polsce są niewystarczające. PPP (partnerstwo publiczno-prywatne) stanowi kombinację zaangażowania prywatnego i publicznego kapitału $\mathrm{w}$ celu realizacji zadań pozostających tradycyjnie w gestii władz publicznych. PPP daje szansę na zwiększenie ilości przedsięwzięć publicznych, przy jednoczesnym zwiększeniu jakości dostarczanych usług. Celem artykułu jest analiza zakresu stosowania formuły partnerstwa publiczno-prywatnego (PPP) w Polsce w 2011 roku oraz ocena możliwości jej zastosowania przy realizacji programów rewitalizacji miast.

\section{Summary}

\section{PUBLIC-PRIVATE PARTNERSHIP AS A FUNDING MECHANISM FOR REVITALIZATION OF CITIES IN THE PERSPECTIVE OF YEAR 2020}

Traditional sources of financing municipal investments in Poland are insufficient. PPP is a combination of activities of public and private capital for the implementation of the tasks that previously remained in the domain of public activity. The division of powers in carrying out public tasks of economic and political powers gives the opportunity to increase the volume of public services and to increase the efficiency of their delivery. Public-private partnership is necessary and there is a need to disseminate knowledge about how to carry out public tasks through PPP in the Polish reality. 